\title{
PERSEPSI REMAJA TERHADAP ATRIBUT KENYAMANAN PADA SETTING ALUN-ALUN PURWOKERTO SEBELUM DI RENOVASI
}

\author{
Yohanes Wahyu Dwi Yudono \\ Program Studi Teknik Arsitektur Fakultas Teknik, Universitas Wijayakusuma Purwokerto \\ wahyuyudono@gmail.com
}

\begin{abstract}
Abstrak
Pemahaman suatu lingkungan fisik, didasarkan pada persepsi pengguna terhadap properti yang ada di dalam settingnya. Persepsi tidak bersifat pasif dalam menerima masukan yang berupa stimulus yang berasal dari luar diri manusia. Selanjutnya melalui keberadaan properti yang ada di dalam setting yang berlaku sebagai stimulus, akan dikirimkan dari mata ke otak untuk dipahami dan diberi makna berdasarkan pengalaman masing-masing pengguna. Dengan demikian dapat dirumuskan tentang dugaan penyebab munculnya makna ganda pada fenomena setting alun-alun Purwokerto, yaitu adanya perbedaan persepsi sebagai akibat pegeseran fungsi dalam konsepsi ruang berkumpul. Adapun perbedaan persepsi yang dimaksud, menyangkut faktor internal individu (pengguna alun-alun, dalam hal ini remaja) yang berupa motiv, harapan, dan minat remaja terhadap setting alun-alun. Penelitian ini dilakukan untuk melihat hubungan keterkaitan antara persepsi remaja terhadap atribut ruang berkumpul pada setting alun-alun Purwokerto. Teori operasional dibangun dengan mendasarkan pada teori Weismann (1981) tentang atribut sebagai variabel bebas, serta teori Paull. A. Bell, dkk (1978) tentang persepsi dan teori Atkinson Rita. L, dkk (1983) tentang faktor internal sebagai variabel terikat. Sedangkan metoda analisis yang digunakan dalam penelitian ini adalah dengan perhitungan statistik deskriptif. Penelitian ini dilakukan untuk melihat hubungan keterkaitan antara persepsi remaja terhadap atribut kenyamanan ruang berkumpul pada setting alunalun Purwokerto. Sedang hasil penelitian menunjukan: persepsi remaja terhadap atribut kenyamanan berdasar kondisi udara segar 32,65\%, kondisi pencahayaan $26,53 \%$, dan kondisi ketenangan suasana $14,28 \%$.
\end{abstract}

Kata Kunci: Persepsi, Atribut, Kenyamanan.

\begin{abstract}
Understanding of a physical environment, based on the user's perception of the properties that exist in the setting. Perception is not passive in accepting input in the form of stimulus originating from outside of humans. Furthermore, through the existence of properties in settings that act as stimuli, will be sent from the eye to the brain to be understood and given meaning based on the experience of each user. Thus it can be formulated about the alleged cause of the emergence of multiple meanings in the phenomenon of the setting of the Purwokerto square, namely the difference in perception as a result of shifting functions in the conception of a gathering / public space. As for the different perceptions referred to, concerning individual internal factors (users of the square, in this case adolescents) in the form of motivation, hopes, and interests of adolescents towards setting the square. This research was conducted to see the relationship between adolescents' perceptions of the attributes of the gathering space in the Purwokerto square setting. Operational theory builds on Weismann's (1981) theory of attributes as independent variables, and Paull's theory. A. Bell, et al (1978) about Atkinson Rita's perception and theory. L, et al (1983) concerning internal factors as dependent variables. While the method of analysis used in this research is descriptive statistical calculations. This research was conducted to see the relationship between the perceptions of adolescents on the comfort attributes of gathering spaces in the Purwokerto square setting. While the results of the study showed: adolescents' perceptions of comfort attributes based on fresh air conditions $32.65 \%$, lighting conditions $26.53 \%$, and conditions of calm atmosphere $14.28 \%$.
\end{abstract}

Keywords: Perception, Attributes, Comfort. 


\section{PENDAHULUAN}

Sistem persepsi tidak menerima masukan secara pasif tetapi berupaya untuk mencari penghayatan yang paling sesuai dengan data sensorik. Dalam kebanyakan situasi, hanya terdapat satu penafsiran data sensorik yang masuk akal, dan pencarian terhadap penghayatan yang tepat, berlangsung begitu cepat dan secara otomatik sehingga tidak disadari oleh manusia (Atkinson, Rita. L, dkk. 1983:221). Data sensorik yang diterima manusia melalui sel-sel reseptor dalam proses penginderaan, disebabkan oleh adanya stimulus yang berasal dari luar diri manusia, kemudian sejumlah penginderaan tersebut disatukan dan dikoordinasikan didalam pusat syaraf (otak) untuk dikenali dan dinilai. Proses demikian disebut persepsi.

Aktifitas mengenali objek atau lingkungan fisik merupakan aktifitas mental, dimana otak tidak secara pasif dalam menggabungkan kumulasi (tumpukan) pengalaman dan memori, melainkan aktif untuk menilai dan memberi makna terhadap objek atau lingkungan fisik yang dapat berlaku sebagai stimulus bagi manusia sebagai pengguna. Dengan demikian penghayatan dapat dikatakan sebagai upaya untuk mendapatkan tafsiran yang prima dari informasi sensorik berdasarkan pengetahuan manusia terhadap benda / lingkungan fisiknya.

Menurut Brogden, F dalam Snyder (1991), keberadaan suatu ruang tidak berdiri sendiri, melainkan saling berhubungan, dimana pengaruh suatu ruang tergantung pada ruang- ruang yang terletak sebelum dan sesudahnya. Dimana urutan ruang harus fungsional dan mudah untuk dipahami. Proses pemahaman terhadap suatu ruang (lingkungan fisik), didasarkan pada persepsi pengguna terhadap properti yang ada didalam settingnya. Melalui keberadaan properti yang ada didalam setting yang berlaku sebagai stimulus, akan dikirimkan dari mata ke otak untuk dipahami dan diberi makna berdasarkan pengalaman masing-masing pengguna. Menurut Cullen dalam Brogden (1991), penyusunan suatu ruang didasarkan pada urutan kayalan yang bersifat serial dari bagian terkecil untuk dikembangkan pada konteks yang lebih besar. Urutan kayalan yang dimaksud adalah kesinambungan dalam persepsi untuk mendapatkan pemahaman mengenai fungsi ruang. Kesalahan dalam mengurutkan kesinambungan persepsi, akan didapatkan pemahaman fungsi ruang yang bermakna ganda (ambiguous).

Fenomena yang terjadi pada setting alun-alun di Purwokerto, mengindikasikan adanya pergeseran fungsi sebagai akibat pergeseran konsepsi ruang oleh pengguna (pada penelitian ini mengkhususkan pada remaja). Menurut Hiller Bill (1984), pengalaman terhadap ruang adalah landasan dan bingkai dari semua pengetahuan terhadap dunia kita yang bersifat spasio-temporal, dan setiap pikiran yang bersifat abstrak adalah usaha untuk menyeberangi (transcend) bingkai tersebut. sampai-sampai ada usaha untuk menghilangkan dimensi ruang didalam pengalaman manusia. 
Fenomena demikian menurut Zahnd, proses lingkaran tersebut berjalan satu kali saja, Markus telah dikatakan sejak tahun 1967, melainkan berputar terus.

pendapat ini lebih ditegaskan oleh Arendt dalam Zahnd, Markus (1999) bahwa: "Kota tidak seharusnya dimengerti sebagai penentuan lokalitas secara geografis, melainkan sebagai sebuah struktur organisasi masyarakat yang saling bertindak dan berkomunikasi; ruang kota sebenarnya ada diantara orang yang hidup dengan maksud tersebut".

Walaupun di masa depan sistem jaringan komunikasi cenderung mengakibatkan jaringan kota yang lebih kompleks pula, tetapi tidak mungkin ada kota yang sifatnya abstrak saja atau spaceless (tanpa ruang). Kuantitas dan kualitas ruang tetap dibutuhkan walaupun pola dan bentuknya mungkin akan berbeda untuk masyarakat di masa depan. Bagaimanakah menciptakan ruang perkotaan yang memiliki potensi yang baik secara kuantitatif dan kualitatif ?

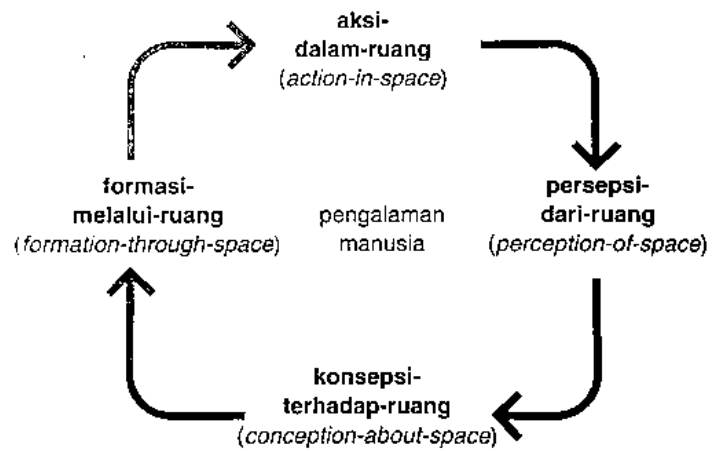

Bagan: I - 1 - Sumber: Zahnd, Markus (1999) Lingkaran Dinamika Pengalaman Spasial oleh Manusia.

Lingkaran Diagram: I-1 tersebut, tidak berjalan secara mulus dan tahapnya tidak dapat dipisahkan dengan tegas karena agak kabur. Oleh sebab itu, tidak boleh dianggap bahwa
Menurut Brogden dalam Snyder (1991), persepsi suatu ruang ditentukan oleh dua hal, yaitu: cara ruang digunakan dan kedua; penyusunan/pengaturan ruang beserta unsurunsurnya (properti) yang dapat mempengaruhi sikap pengguna (remaja). Lebih lanjut dijelaskan oleh Berkowitz 1972 dalam Azwar (2002), bahwa sikap adalah perasaan mendukung atau memihak (favorable) maupun perasaan tidak mendukung atau tidak memihak (unfavorable) pada suatu objek. Lebih lanjut dijelaskan oleh Azwar (2002), bahwa interaksi antara situasi lingkungan dengan sikap, dengan berbagai faktor didalam maupun di luar diri individu akan membentuk suatu proses kompleks yang akhirnya menentukan bentuk perilaku seseorang. Dengan demikian dapat dikatakan bahwa sikap merupakan ungkapan perasaan yang bersifat individu, sebagai produk ungkapan faktor internal yang bersifat individual. Menurut Atkinson Rita. L, dkk (1983), sifat individual dapat ditunjukan dengan adanya motif, harapan, dan minat individu tersebut.

Dengan demikian dapat dirumuskan tentang dugaan penyebab munculnya makna ganda pada fenomena setting alun-alun Purwokerto, yaitu adanya perbedaan persepsi sebagai akibat pegeseran fungsi dalam konsepsi ruang berkumpul / publik. Adapun perbedaan persepsi yang dimaksud, menyangkut faktor internal individu (pengguna alun-alun, dalam hal ini 
remaja) yang berupa motiv, harapan, dan minat remaja terhadap setting alun-alun.

Dari uraian diatas, dapat ditarik suatu permasalahan untuk dilakukan penelitian guna mengetahui keterkaitan antara persepsi remaja terhadap atribut ruang berkumpul (publik) pada setting alun-alun yang dapat memunculkan makna ganda.

\section{TUJUAN PENELITIAN:}

Tujuan penelitian ini adalah mengkaji setting alun-alun sebagai ruang berkumpul / publik, dengan mengkaitkan faktor persepsi sebagai produk interaksi individu dengan setting dan faktor atribut sebagai produk interaksi antara individu / kelompok individu dalam settingnya.

Adapun temuan yang diharapkan dalam penelitian ini, adalah:

Mengetahui sejauh mana keterkaitan persepsi remaja dengan atribut ruang berkumpul / publik pada alun-alun Purwokerto.

\section{BATASAN MASALAH:}

Dalam penelitian ini dilakukan batasan-batasan yang menyangkut pada objek kajian, waktu pelaksanaan pengambilan data sampel/ responden, dan landasan konsep/teori operasional, yang masing-masing dijabarkan sebagai berikut:

a. Objek kajian:

Dibatasi pada setting alun-alun Purwokerto yang diduga bermakna ganda, sebagai akibat peran stimulus (dalam hal ini, pergeseran fungsi dalam konsepsi ruang berkumpul/publik) terhadap persepsi remaja sebagai pengguna.

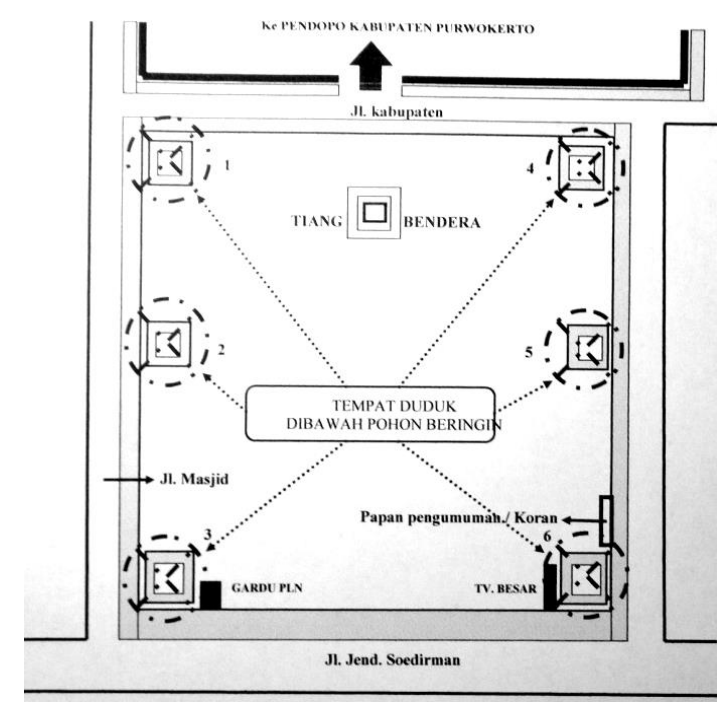

Gambar. 1 Sketsa Alun-alun Purwokerto Sebagai Objek Penelitian

b. Waktu Pelaksanaan:

Dalam pengambilan data sampel / responden, menyesuaikan saat-saat setting alun-alun dipakai oleh pengguna, dengan mengalokasikan waktu pengambilan data pada: awal bulan, pertengahan bulan, dan akhir bulan.

c. Landasan Teori / Landasan Konsep:

Dibangun dengan mendasarkan pada paham rasionalistik dengan cara pemecahan bersifat kualitatif.

\section{MANFAAT PENELITIAN:}

a. Memberikan sumbangan terhadap perkembangan ilmu pengetahuan khususnya arsitektur perilaku, yang berkaitan dengan perilaku manusia terhadap lingkungan (fisik).

b. Sebagai langkah awal dalam rekam jejak untuk melakukan penelitian pada objek yang sama dengan pengguna yang berbeda. 


\section{ALUR PIKIR PENELITIAN:}

Penelitian ini merupakan penelitian kuantitatif, yang didasarkan pada filsafat rasionalisme, dimana teori operasional dibangun dengan cara memberikan permaknaan yang didasarkan pada empiri sensual, logik, dan etik terhadap teori Weismann (1981), teori Paul. A. Bell, dkk (1978), dan teori Atkinson Rita. L, dkk (1983), dengan tetap mengkaitkan kondisi realitas dari objek penelitian.

Untuk memperjelas alur pola pikir penelitian yang terbagi kedalam dua bagian pokok, yaitu: pertama, bagian temuan problematik dan teori (berisi tentang fenomena yang terjadi pada setting alun-alun, sebagai objek penelitian untuk diamati salah satu dari problematiknya dengan mengajukan alat untuk mengkaji problematik tersebut), dan kedua, bagian dugaan dan pemecahannya (berisi tentang dugaan sementara dari problematik yang terjadi, yang akan dipecahkan dengan paham rasionalistik secara kuantitatif). Dari hasil model pendekatan tersebut, terhadapnya akan diperlakukan sebagai alat untuk mengkaji persepsi remaja sebagai pengguna terhadap setting alun-alun yang mengandung atribut ruang berkumpul sebagai faktor penyebab munculnya makna ganda.

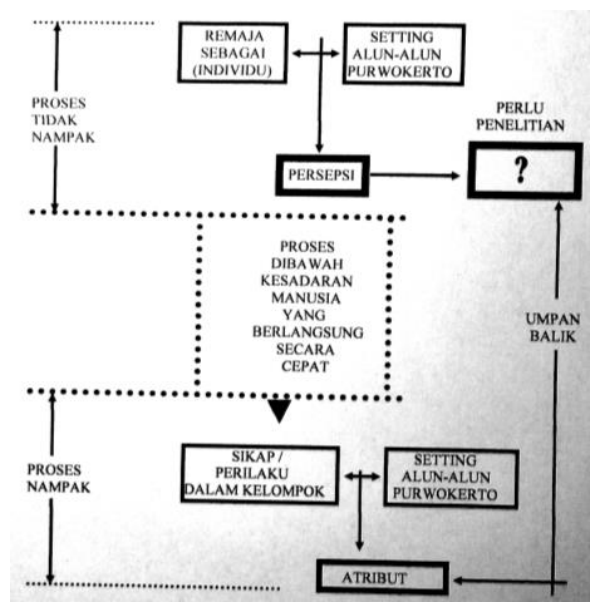

Gambar 2. Permasalahan / Problematik Penelitian

\section{VARIABEL PENELITIAN:}

Terdapat 2 variabel penelitian yaitu variabel bebas / pengaruh dan variabel terikat / terpengaruh. Adapun wujud dari kedua variabel tersebut adalah:

\begin{tabular}{|l|l|}
\hline $\begin{array}{l}\text { 1. Variabel } \\
\text { terikat/terpengar } \\
\text { uh }\end{array}$ & $\begin{array}{l}\text { Persepsi remaja } \\
\text { terhadap setting alun- } \\
\text { alun Purwokerto yang } \\
\text { dijaring melaui Motiv, } \\
\text { Harapan, dan Minat } \\
\text { remajaran didalam } \\
\text { melakukan kegiatan } \\
\text { interaksi sosial }\end{array}$ \\
\hline $\begin{array}{l}\text { 2. Variabel bebas/ } / \text { ruang } \\
\text { pengaruh }\end{array}$ & $\begin{array}{l}\text { Atribut informal, } \\
\text { berkumpul menerapkan } \\
\text { dengan (1981) } \\
\text { teori Weismann } \\
\text { sebagai indikator untuk } \\
\text { mengamati setting alun- } \\
\text { alun Purwokerto. }\end{array}$ \\
\hline
\end{tabular}

Agar jelas tentang variabel yang diamati dalam penelitian, dapat dilihat Tabel: 1; tentang variabel terikat / terpengaruh, dan Tabel: 2; tentang variabel bebas / pengaruh. 
Tabel: 1

Keterkaitan antara Variabel Terikat, Indikator, dan Tolok Ukur Penelitian

\begin{tabular}{|c|c|c|c|}
\hline $\begin{array}{l}\text { VARIABEL } \\
\text { TERIKAT }\end{array}$ & $\begin{array}{c}\text { INDIKATOR } \\
\text { PERSEPSI }\end{array}$ & \multicolumn{2}{|c|}{ TOLOK UKUR } \\
\hline \multirow{7}{*}{$\begin{array}{c}\text { PERSEPSI } \\
\text { REMAJA } \\
\text { TERHADAP } \\
\text { SETTING } \\
\text { ALUN-ALUN } \\
\text { PURWOKERTO }\end{array}$} & MOTIV & 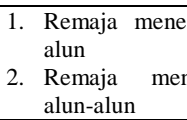 & $\begin{array}{l}\text { ing setting alun- } \\
\text { suaikan setting }\end{array}$ \\
\hline & HARAPAN & 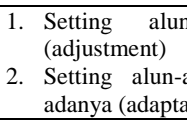 & $\begin{array}{l}\text { Iun di rubah } \\
\text { n dibiarkan apa }\end{array}$ \\
\hline & \multirow{5}{*}{ MINAT } & $\begin{array}{l}\text { TUJUAN } \\
\text { MINAT }\end{array}$ & $\begin{array}{l}\text { BENTUK } \\
\text { MINAT }\end{array}$ \\
\hline & & IMITASI & $\begin{array}{ll}\text { 1. } & \text { Baaca } \\
\text { 2. } & \text { Diskusi } \\
\text { 3. } & \text { Ngobrol }\end{array}$ \\
\hline & & SUGESTI & $\begin{array}{ll}\text { 1. } & \text { Baca } \\
\text { 2. } & \text { Diskusi } \\
\text { 3. } & \text { Ngobrol } \\
\end{array}$ \\
\hline & & IDENTIFIKASI & $\begin{array}{ll}\text { 1. } & \text { Baca } \\
\text { 2. } & \text { Diskusi } \\
\text { 3. } & \text { Ngobrol }\end{array}$ \\
\hline & & SIMPATI & $\begin{array}{ll}\text { 1. } & \text { Baca } \\
\text { 2. } & \text { Diskusi } \\
\text { 3. } & \text { Ngobrol } \\
\end{array}$ \\
\hline
\end{tabular}

Dengan mendasarkan pada penyederhanaan teori Weismann (1981) tentang fenomena perilaku yang berupa atribut dalam penelitian Wahyu (2003), maka variabel bebas dalam penelitian ini adalah sebagai yang terlihat dalam Tabel: 2 .

Tabel: 2

Keterkaitan antara Variabel Bebas, Indikator, dan Tolok Ukur Penelitian.

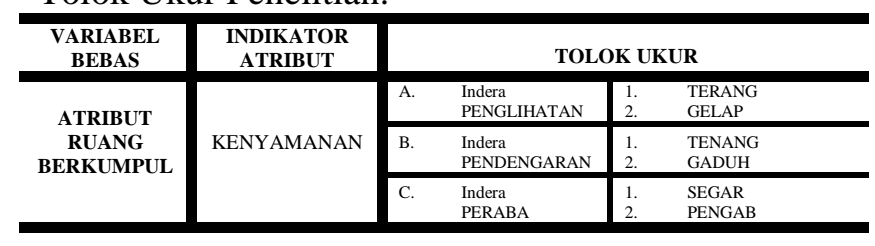

\section{TEMUAN PENELITIAN:}

Gambar 3. Grafik 1. Hasil Analisa Persepsi remaja terhadap atribut kenyamanan pada setting alun-alun Purwokerto dalam motiv menyesuaikan dengan bentuk harapan yang adaptif:

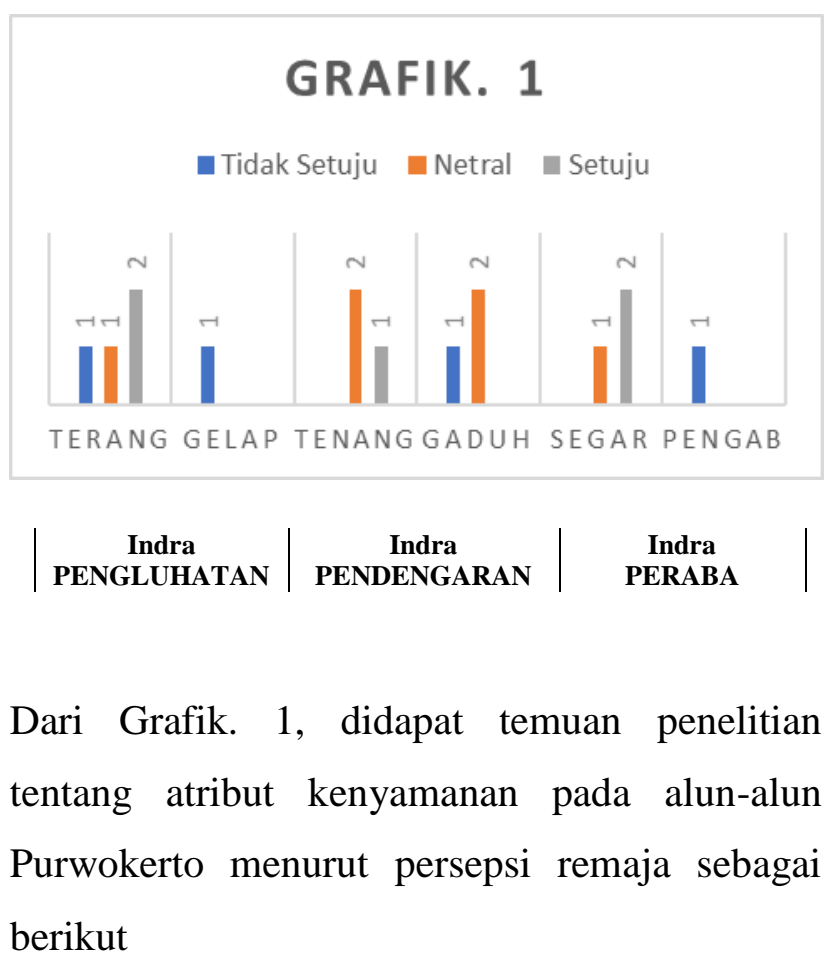

a. Setting alun-alun oleh remaja dari indera penglihatan diperlihatkan pernyataan Tidak Setuju (2,04\%), Netral (2,04\%), Setuju $(4,08 \%)$ terhadap kesan Terang dan Tidak Setuju (2,04\%) terhadap kesan Gelap.

b. Setting alun-alun oleh remaja dari indera penglihatan diperlihatkan pernyataan Netral $(4,08 \%)$, Setuju $(2,04 \%)$ terhadap kesan Tenang dan Tidak Setuju (2,04\%), Netral $(2,04 \%)$ terhadap kesan Gaduh.

c. Setting alun-alun oleh remaja dari indera penglihatan diperlihatkan pernyataan Netral $(2,04 \%)$, Setuju $(4,08 \%)$ terhadap kesan Segar dan Tidak Setuju (2,04\%), Netral $(2,04 \%)$ terhadap kesan Pengab.

Gambar 4 Grafik 2 Hasil Analisa Persepsi remaja terhadap atribut kenyamanan pada setting alun-alun Purwokerto dalam motiv menyesuaikan dengan bentuk harapan yang adjustment: 


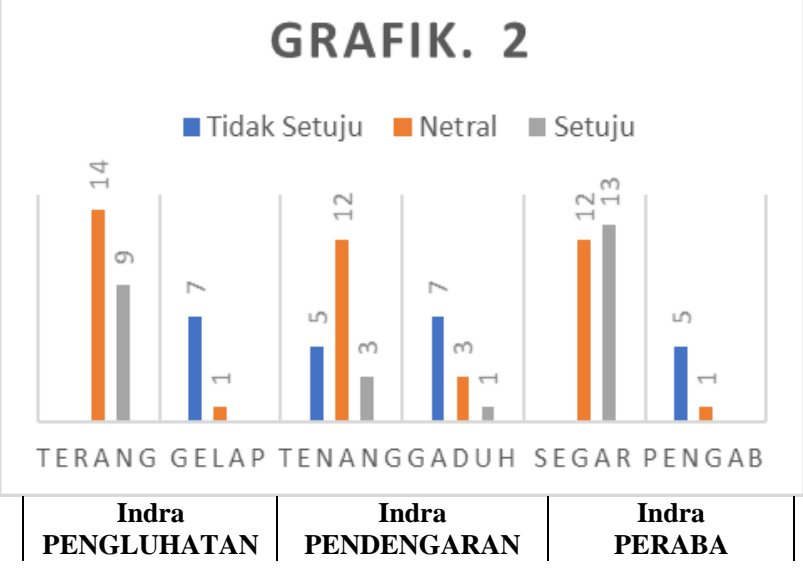

Dari Grafik. 2, didapat temuan penelitian tentang atribut kenyamanan pada alun-alun Purwokerto menurut persepsi remaja sebagai berikut

a. Setting alun-alun oleh remaja dari indera penglihatan diperlihatkan pernyataan Netral $(28,57 \%)$, Setuju $(18,36 \%)$ terhadap kesan Terang dan Tidak Setuju (14,28\%), Netral $(2,04 \%)$ terhadap kesan Gelap.

b. Setting alun-alun oleh remaja dari indera penglihatan diperlihatkan pernyataan Tidak Setuju (10,2\%), Netral $(24,48 \%)$, Setuju $(6,12 \%)$ terhadap kesan Tenang dan Tidak Setuju (14,28\%), Netral (6,12\%), Tidak Setuju (2,04\%) terhadap kesan Gaduh.

c. Setting alun-alun oleh remaja dari indera penglihatan diperlihatkan pernyataan Netral $(24,48 \%)$, Setuju $(26,53 \%)$ terhadap kesan Segar dan Tidak Setuju (10,2\%), Netral $(2,04 \%)$ terhadap kesan Pengab.

Gambar 5. Grafik. 3: Hasil Analisa Persepsi remaja terhadap atribut kenyamanan pada setting alun-alun Purwokerto dalam motiv menentang dengan bentuk harapan yang adaptif:

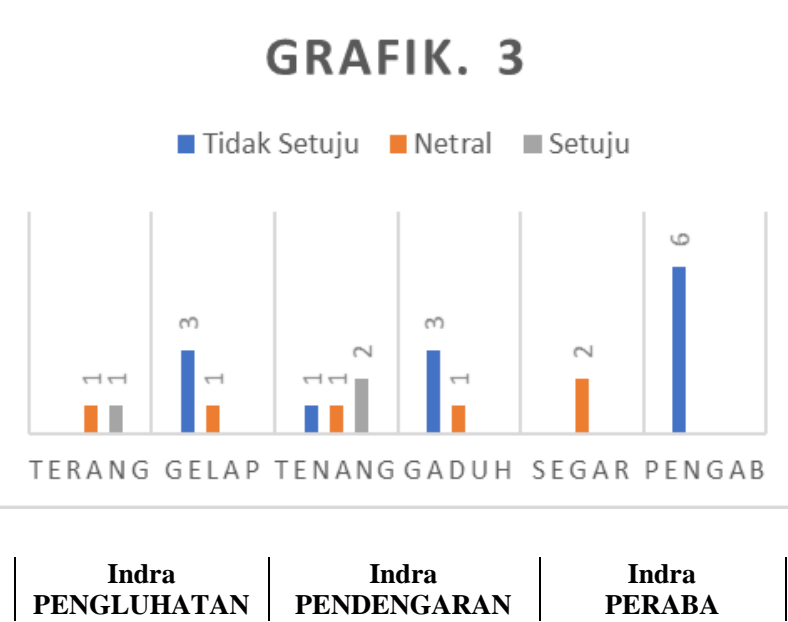

Dari Grafik. 3, didapat temuan penelitian tentang atribut kenyamanan pada alun-alun Purwokerto menurut persepsi remaja sebagai berikut

a. Setting alun-alun oleh remaja dari indera penglihatan diperlihatkan pernyataan Netral $(4,08 \%)$, Setuju $(4,08 \%)$ terhadap kesan Terang dan Tidak Setuju (6,12\%), Netral $(2,04 \%)$ terhadap kesan Gelap.

b. Setting alun-alun oleh remaja dari indera penglihatan diperlihatkan pernyataan Tidak Setuju (2,04\%), Netral (2,04\%), Setuju $(4,08 \%)$ terhadap kesan Tenang dan Tidak Setuju (6,12\%), Netral (2,04\%) terhadap kesan Gaduh.

c. Setting alun-alun oleh remaja dari indera penglihatan diperlihatkan pernyataan Netral (4,08\%) terhadap kesan Segar dan Tidak Setuju $(12,24 \%)$ terhadap kesan Pengab.

Gambar 6. Grafik. 4: Hasil Analisa Persepsi remaja terhadap atribut kenyamanan pada setting alun-alun Purwokerto dalam motiv menentang dengan bentuk harapan yang adjustment: 


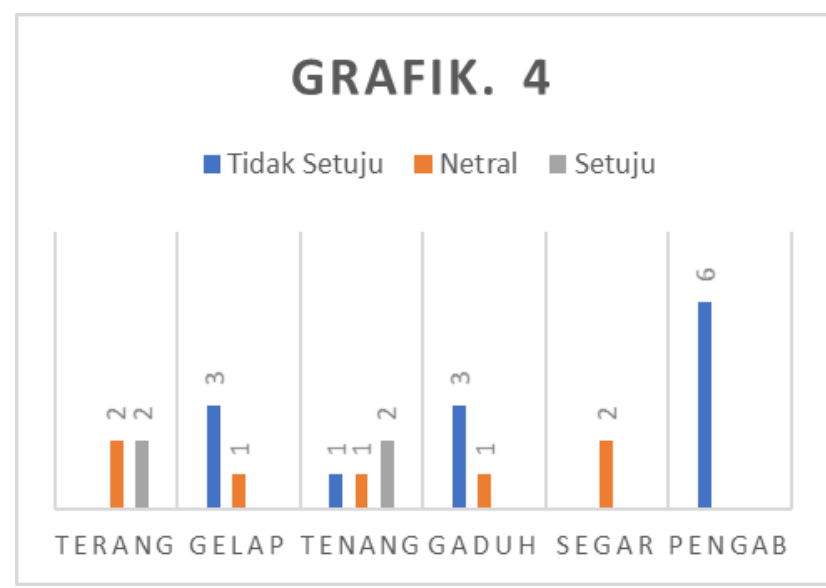

\begin{tabular}{|l|c|c|} 
Indra & Indra & Indra \\
PENGLUHATAN & PENDENGARAN & PERABA
\end{tabular}

Dari Grafik. 4, didapat temuan penelitian tentang atribut kenyamanan pada alun-alun Purwokerto menurut persepsi remaja sebagai berikut

a. Setting alun-alun oleh remaja dari indera penglihatan diperlihatkan pernyataan Netral (6,12\%) terhadap kesan Terang dan Tidak Setuju (2,04\%), Netral (2,04\%) terhadap kesan Gelap.

b. Setting alun-alun oleh remaja dari indera penglihatan diperlihatkan pernyataan Setuju (2,04\%) terhadap kesan Tenang dan Tidak Setuju (4,08\%), Netral (4,08\%) terhadap kesan Gaduh.

c. Setting alun-alun oleh remaja dari indera penglihatan diperlihatkan pernyataan Netral $(4,08 \%)$, Setuju $(2,04 \%)$ terhadap kesan Segar dan Tidak Setuju (2,04\%), Netral $(2,04 \%)$ terhadap kesan Pengab.

\section{KESIMPULAN:}

Setting alun-alun Purwokerto memiliki 6 pohon beringin (tanpa adanya Ringin Kurung), yang masing-masing 3 pohon berderet disebelah Timur dan 3 pohon lainnya berderet di sebelah
Barat yang berpotensi sebagai tempat untuk melakukan kegiatan interaksi sosial.

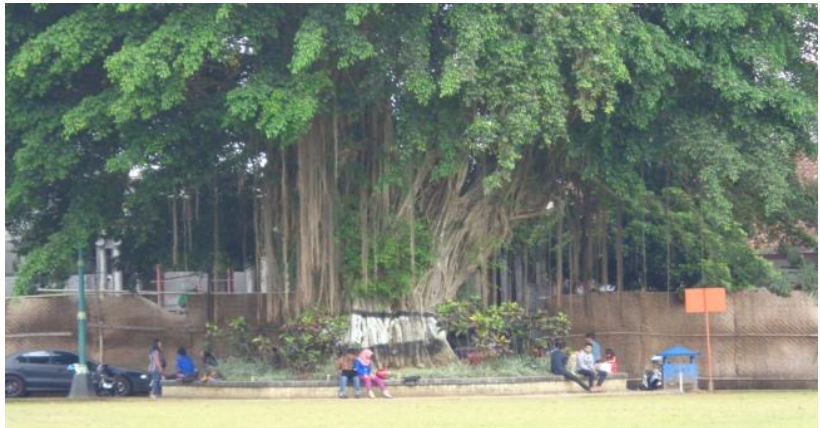

Gambar. 7: salah satu properti (berupa pohon beringin) yang digunakan untuk melakukan kegiatan interaksi sosial pada alun-alun Purwokerto (salah satu pohon yang berada di deretan sebelah Timur)

Pada tulisan ini memaparkan hasil penelitian terhadap 50 responden remaja (1 kuestioner rusak / tidak dapat untuk mendeteksi persepsi), tentang atribut kenyamanan properti pada setting alun-alun Purwokerto. Dari uraian temuan penelitian, menurut persepsi remaja setting alun-alun dapat disimpulkan bahwa:

a. Mendasarkan indera peraba: melakukan kegiatan interaksi sosial di alun-alun terasa nyaman karena ditunjang oleh kondisi kesegaran udara $(32,65 \%)$.

b. Mendasarkan indera penglihatan: melakukan kegiatan interaksi sosial di alunalun terasa nyaman karena ditunjang oleh kondisi terang cahaya yang ada $(26,53 \%)$

c. Mendasarkan indera pendengaran: melakukan kegiatan interaksi sosial di alunalun terasa nyaman karena ditunjang oleh kondisi ketenangan suasana $(14,28 \%)$.

\section{DAFTAR PUSTAKA}

Atkinson, Rita.L, dkk (1983), Pengantar Psikologi jilid. 1, Erlangga, Jakarta. 

, (1999), Pengantar Psikologi jilid. 2, Erlangga, Jakarta.

Azwar, S (2002), Sikap Manusia Teori dan Pengukurannya, Pustaka Pelajar Offset, Yogyakarta.

Bagoes. P.W (2001), Pijar-Pijar Penyingkap Rasa, PT.Gramedia Pustaka Utama, Jakarta.

Bimo Walgito, Prof. Dr (1994), Psikologi Sosial, Andi Offset, Yogyakarta.

Brogden,F, Perencanaan dan Perancangan Tapak, dalam: Snyder, James.C \& Catanese, Anthony.J, (1991), Pengantar Arsitektur, Erlangga, Jakarta. P:179-215

Gerungan.WA (2000), Psikologi Sosial, PT.Refika Aditama, Bandung.

Hadi. S (1973), Metodologi Research, untuk penulisan paper, skripsi, thesis dan disertasi, diterbitkan: yayasan penerbit fakultas psikologi UGM, Yogyakarta.

Mediana Desiani, R, (2001), Ekspresi Islami dalam Pola Tata Ruang Kota di Jawa, dalam SNEIDAN. 4, diterbitkan oleh: Program Magister Teknik ArsitekturUNDIP bekerja sama dengan Lembaga Sejarah Arsitektur Indonesia, Semarang.

Noeng Muhadjir. H, Prof. $\operatorname{Dr}$ (2000), Metodologi Penelitian Kualitatif, edisi. IV, penerbit Rake Sarasin, Yogyakarta.

Roem, M, dkk (1982), Tahta untuk Rakyat, PT. Gramedia, Jakarta.

Sarwono, Sarlito. W (1995), Psikologi Lingkungan, PT. Gramedia Widiasarana, Indonesia, Jakarta.

...... , (2001), Psikologi Sosial (psikologi kelompok dan psikologi terapan), Balai Pustaka, Jakarta.

Sears, David. O, dkk (1985), Psikologi Sosial jilid. 2, Erlangga, Jakarta.

Setiawan. B, Haryadi (1995), Arsitektur Lingkungan dan Perilaku, Direktorat
Jenderal Pendidikan Tinggi Departemen Pendidikan dan Kebudayaan.

Soelarto. B (1993), Garebeg di Kesultanan Yogyakarta, Kanisius, Yogyakarta.

Wiryomartono, A. Bagoes, P, (1995), Seni Bangunan dan Seni Binakota di Indonesia, Jakarta, PT. Gramedia Pustaka Utama.

Yudono, Wahyu. DY, (2003), Persepsi Mahasiswa terhadap Setting Tangga dalam Hall, Tesis, Universitas Diponegoro, Semarang.

Zahnd, Markus (1999), Perancangan Kota secara Terpadu, Kanisius, Yogyakarta 